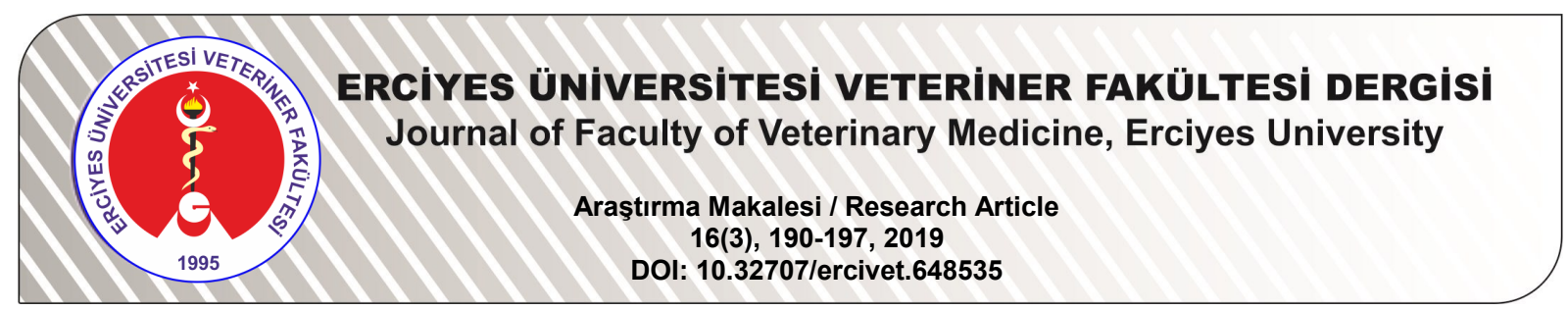

\title{
Kayseri İlinde Satışa Sunulan Sokak Sütlerinde Mycobacterium paratuberculosis Varlığının Konvansiyonel ve Serolojik Yöntemlerle Araştırılması*
}

\author{
Meral ÖZTÜRK KALIN ${ }^{1}$ K. Semih GÜMÜŞSOY², Harun HIZLISOY ${ }^{3}$ \\ ${ }^{1}$ Erciyes Üniversitesi Tıp Fakültesi, Genel Cerrahi Servisi, Kayseri, TÜRKIYE \\ ${ }^{2}$ Erciyes Üniversitesi Veteriner Fakültesi, Mikrobiyoloji Anabilim Dalı, Kayseri, TÜRKIYE \\ ${ }^{3}$ Erciyes Üniversitesi Veteriner Fakültesi, Veteriner Halk Sağlığı Anabilim Dalı, Kayseri, TÜRKIYE
}

\begin{abstract}
*Sorumlu yazar: Prof. Dr. Kadir Semih GÜMÜŞSOY; E-posta: ksemih38@gmail.com; ORCID: 0000-0001-6326-0377 Atıf yapmak için: Öztürk Kalın M, Gümüşsoy KS, Hızlısoy H. Kayseri ilinde satışa sunulan sokak sütlerinde Mycobacterium paratuberculosis varlığının konvansiyonel ve serolojik yöntemlerle araştırılması. Erciyes Üniv Vet Fak Derg 2019; 16(3): 190-197.
\end{abstract}

Özet: Bu çalışmada Kayseri ilinde satışa sunulan sokak sütlerinde Mycobacterium avium subsp. paratuberculosis (MAP)'in varlığı konvansiyonel ve serolojik yöntemlerle araştırılması amaçlandı. Araştırmada Mayıs 2010 - Ekim 2011 yılları arasında Kayseri'nin ilçelerinden farklı satıcılardan 200 çiğ inek süt örneği toplandı. Her bir süt numunesi direkt mikroskopi, kültür ve serolojik yöntem olmak üzere üç aşamada değerlendirdi. Direkt mikroskopide süt örneklerinden hazırlanan preparatlar Ziehl-Neelsen boyama metodu ile boyandı. Ayrıca besiyerlerinden izole edilen şüpheli kolonilerin boyamasında da aynı yöntem kullanıldı. Etken izolasyonu amacıyla süt numunelerinin bakteriyolojik ekimleri gliserinli ve gliserinsiz Löwenstein-Jensen ve Watson-Reid agara yapıldı. İdentifikasyon için katalaz, niasin, nitrat redüksiyon, pirazinamidaz ve üreaz testleri kullanıldı. Sütteki antikorların araştııılmasında Mycobacterium paratuberculosis Enzyme-Linked ImmunoSorbent Assay (ELISA) kitinden yararlanıldı. İncelenen örneklerde üç yönteminin kullanılması sonucu sadece 1 numunede (\% 0.5) MAP tespit edildi. Sonuç olarak, Kayseri ilinde satışa sunulan sokak sütlerinde paratüberkülozun yüksek oranda bulunmadığı belirlendi. Ancak bir örnekte etkenin tespiti infeksiyonun önemi göz önünde bulundurulduğunda halk sağlığı açısından önemli risk oluşturabileceği kanaatini ortaya koymuştur.

Anahtar kelimeler: ELISA, identifikasyon, izolasyon, Mycobacterium paratuberculosis, sokak sütü

\section{The Investigation of Mycobacterium paratuberculosis by Serological and Cultural Methods in Raw Milks} Retailed in Kayseri

Summary: In this study, it was aimed to investigate the presence of Mycobacterium avium subsp. paratuberculosis (MAP) in raw milk sold in Kayseri province by conventional and serological methods.

Between May 2010 and October 2011, 200 raw cow milk samples were collected from various sellers of the Kayseri provinces. Each milk sample was evaluated in three steps including direct microscopy, culture and serological method. Preparations from milk samples were stained with Ziehl-Neelsen staining method in direct microscopy method. In addition, the same method was used for the staining of suspicious colonies isolated from the media. For the purpose of isolation, the bacteriological inoculation of milk samples was carried out onto Watson-Reid agar and LöwensteinJensen supplemented with and without glycerin. Catalase, niacin, nitrate reduction, pyrazinamidase and urease tests were performed for the identification. Mycobacterium paratuberculosis Enzyme-Linked ImmunoSorbent Assay (ELISA) kit was used for the detection of antibodies in milk samples. MAP was detected in only one sample $(0.5 \%)$ with the using of three identification methods. As a result, it has been understood that paratuberculosis was not found at high rate in raw milk sold in Kayseri province. However, it has been concluded that the presence of an agent in one sample may pose a significant risk for public health when considering the importance of infection.

Key words: ELISA, identification, isolation, Mycobacterium paratuberculosis, raw milk

\section{Giriş}

Paratüberkülozis (Johne's Disease) Mycobacterium avium supsp. paratuberculosis (MAP) tarafından sığır, koyun ve keçi başta olmak üzere deve, manda, antilop ve geyikler gibi birçok evcil ve vahşi hayvanda gözlenen infeksiyoz ve bulaşıcı bir hastalıktır $(7,17)$.

Geliş Tarihi/Submission Date : 25.12.2018

Kabul Tarihi/Accepted Date : 01.04.2019

${ }^{*} \mathrm{Bu}$ araştırma ilk isimli araştırıcının Yüksek Lisans tezinden üretilmiş olup, Erciyes Üniversitesi Bilimsel Araştırma Projeleri birimi tarafından TSY-10-1089 kodlu proje ile desteklenmiştir.
Paratüberküloz veya Johne hastalığı tüm dünyada olduğu gibi ülkemizde sığırlarda önemli ekonomik kayıplara yol açan infeksiyon olma özelliğini hala korumaktadır. Ruminantlarda başlıca sindirim sistemi etkilenmekte ve kontagiyöz, kronik ve ölümcül bir seyir görülmektedir. İnfekte hayvanların özellikle dışkıları ile çevreyi sürekli kontamine etmeleri önemli bir sorundur. Bu bakımdan infekte sığırların kısa süre içerisinde tespit edilmesi önem arz etmektedir. İnfeksiyonun zoonotik bir boyutu şu an için olmamasına rağmen sığırlarda hastalığı meydana getiren Mycobacterium avium subsp. paratuberculosis (MAP) ile 
insanlarda Crohn hastalığı arasında bir ilişkinin bulunduğu bildirilmekte ve son yıllarda güncel olarak bu konu üzerinde yoğun çalışmalar yapılmaktadır $(18,22)$.

Türkiye'de yıl boyunca elde edilen sütün yüzde \%40'ı pazarlanmakta, pazarlanan kısmın ise \%60'ı işlem görerek tüketici ile buluşmaktadır. İşlem gören sütün \%20'si direk tüketilmekte geriye kalan kısmıda peynir, tereyağ gibi dayanıklı ürün olarak değerlendirilmektedir. Sütün kalitesi, büyük ölçüde, hayvanın temizliği yanı sıra ahır ve görevlilerin hijyeni ile yakından ilgilidir. Zira çiğ sütün dayanıkııı̆ı, büyük ölçüde içerdiği bakteri sayısına, bakterilerin çoğalma hızlarına ve bakterilerin büyüme ve çoğalmaları için geçen süreye bağlı olarak farklılık gösterir. Sütün sağıldığı andaki sıcaklık yaklaşık $35-37^{\circ} \mathrm{C}$ 'dir. Bu sıcaklık dereceleri birçok bakterinin üremesi için elverişlidir. Ayrıca süt üretim yerlerinden işletmeye gelinceye kadar da bir süre geçmektedir. Bu bakımdan bakteriyolojik yönden iyi kalitede sütün elde edilmesi süt üretim yerlerinde başııca; sütün bakterilerle kontaminasyonunun önlenmesi ve sütte normal olarak bulunan ve/veya sonradan bulaşan bakterilerin gelişmelerinin sınırlandırılması için gerekli önlemlerin alınmasına bağlıdır (28). Paratüberkülozun süt sığırlarında, süt üretiminde ve kalitesinde meydana getirdiği ekonomik kayıplar önemli bir yer tutmaktadır (21). Yüksek süt verimli hayvanlarda infeksiyonun görülme sıklığı diğerlerine oranla daha yüksektir (26). Özellikle yaşamın ilk haftalarında kolostrum veya kontamine sütlerin buzağılar tarafından tüketilmesi bulaşmada en önemli kaynak olarak gösterilmiştir (26). Doğal olarak infekte sığırların periparturient döneminde sütlerde MAP'nin düşük miktarlarda bulunduğu, buzağılamadan sonraki 1-2, günlerde kolostrumda en yüksek (50 CFU/ml), 5 . günden sonra bu miktarın (1 CFU/ml) düştüğü ortaya konulmuştur (25). Sütün endojen yolla mı yoksa eksojen yolla mı daha yoğun bulaştığına yönelik bilgiler kıyaslandığında özellikle infekte sığırların dışkıları ile çıkarttıkları etkenlerin $\left(10^{8} \mathrm{CFU} / \mathrm{gr}\right)$ sütü kontamine ettiği tespit edilmiştir (25). MAP ile infekte bir sürüde bazı hayvanlar infekte olmamasına rağmen çoğu hayvan infekte ve subklinik olarak kabul edilmekte ve bir süre sonra bunlar klinik belirtiler gösterebilmektedir. Prepatent dönemdeki hayvanlarda hastalık belirtisi görülmez ve etkenlerin dışkı saçılımı söz konusu değildir. Klinik olarak hayvanlarda kilo kaybı ve ishal başlıca belirtiler olarak görülmekte ve serolojik olarak kanlarında antikor tespit edilmektedir. Genellikle bu dönemde yoğun miktarda dışkı ile bakteri etrafa saçımaktadır (8). Bu hayvanlardan günde yaklaşık olarak $5 \times 10^{12}$ etkenin çıkartıldığı tespit edilmiştir (26). YapıIan birçok çalışmada MAP'ler gıda, süt, su ve etten izole edilmişlerdir $(23,26)$.

Paratüberkülozda ilk tanı klinik verilerle yapılmış olsa bile kesin tanı için etkenin direkt tespiti ve kültürde üretilerek tanımlanması esastır. Bu nedenle tanıda "gold standart" kültür ve klinik tanı birlikteliğidir. Kültür yönteminin spesifitesi yüksek olmasına rağmen sensitivitesi düşüktür (29). Ancak MAP için kültür analizlerinde kısa sürede sonuç elde edilememesi; testin sonuçlanmasının 3 aya kadar uzaması önemli bir dezavantaj olarak görülmektedir. Mikroskobik incelemede aside direncli basilin görülebilmesi için numunede $5 \times 10^{3}-5 \times 10^{4} \mathrm{ml}$ basil bulunması gerekmektedir. Kültürde üreyen mikroorganizmaların saptama sınırı 5-100 CFU arasında değişirken, klinik örneklerde duyarlılık çok daha düşüktür (2).

Paratüberküloz ihbarı mecburi bir hastalık olmadığı için ve gerçek prevalansı ortaya koyacak bir teşhis metodu mevcut olmadığından, hastalığın prevalansı ile ilgili tahminler çoğunlukla kesimhanelerde toplanan materyallerin incelenmesi neticesinde elde edilmiștir. Paratüberkülozlu sürülerde kontrol programlarının gerçekleştirilmesinde en önemli konu sürü içerisinde özellikle subklinik hayvanlar başta olmak üzere dışkı ile saçılım yapan infektif hayvanların tespitidir. Tarama testlerinden istenilen infeksiyonun tanımlanmasında sensitivite ve spesifitesinin yüksek olması, kısa sürede sonuç vermesi ve ekonomik olması başlıca kriterlerdir. Serolojik testler bu kriterlerin çoğuna sahip olmasına rağmen sensitivite ve spesifiteleri yönünden dezavantajlarının bulunduğu birçok araştırıcı tarafından bildirilmiştir $(8,11,29)$. Serolojik testlerden elde edilecek sonuçlar üzerine infeksiyonun aşaması bizzat etkili olmaktadır. Genellikle subklinik ve az miktarda dışkı ile etken çıkarımının sözkonusu olduğu durumlarda serolojik testlerden negatif sonuç alınmaktadır. Bu aşamadaki birçok sığırda humoral antikor yanıtı tanımlanabileceği sınırların altındadır. Hayvanda infeksiyon olmasına rağmen serolojik testlerden negatif sonuçlar alınmaktadır $(1,29)$.

Bu çalışmada MAP' 'in insanlardaki Chrone hastalığının da etkeni olabileceği göz önünde bulundurulduğunda Kayseri ilinde satışa sunulan sokak sütlerinde MAP'in görülme sıklığı ve halk sağlığı açısından risk oluşturma potansiyeli konvansiyonel ve serolojik yöntemlerle araştırııması amaçlandı.

\section{Gereç ve Yöntem}

\section{Süt numuneleri}

Kayseri merkez ve çevre ilçelerinde, mahalle aralarında satışa sunulan toplam 200 sokak süt numunesi Mayıs 2010 - Ekim 2011 yılları arasında toplandı. Süt numuneleri steril poşetler içerisine 0,5 It olacak şekilde bizzat aseptik şartlarda alınarak soğuk zincirde laboratuara getirildi. Laboratuvarda yapılacak analiz yöntemlerine göre herbir süt numunesi 3 adet 50 ml'lik steril falkon içerisine direkt mikroskopi, kültür ve serolojik analizleri yapılmak üzere taksim edildi. Numunelerin direkt mikroskopi ve kültür analizleri aynı gün gerçekleştirildi. Serolojik analizler için sütler soğutmalı santrifüjde 4000 devirde 30 dakika santrifüj edildi. Falkon tüplerin üst kısmında bulunan krema 
kısmı uzaklaştırıldıktan sonra orta kısmındaki plazma kısmı, alt kısımdaki hücresel kısma dokunulmadan bir pipet yardımıyla steril 2 ml'lik ependorflara alındı. Plazmalar serolojik analiz yapılıncaya kadar $-20^{\circ} \mathrm{C}$ 'de saklandı.

\section{Standart suş}

Araştırmada fenotipik analizlerde kullanılan pozitif kontrol suş Etlik Veteriner Kontrol Merkez Araştırma Enstitüsü Tüberküloz Paratüberküloz Ruam Teşhis Laboratuvarı'ndan temin edildi.

\section{Dekontaminasyon}

Süt numuneleri direkt mikroskopi ve kültürel analize tabi tutulmadan önce dekontaminasyon işlemi uygulandı. Bu amaçla Dundee ve ark. (7)'nın bildiridiği yönteme göre 50 ml'lik steril burgulu kapaklı tüplere (Falkon tüpü) alınan süt numuneleri 2500 devirde 15 dk santrifüj edildi. Daha sonra pellet kısmına \%0.75 hexadecylpyridinium chloride (HPC) (Sigma C9002)'den $10 \mathrm{ml}$ ilave edilerek oda Isısında 5 saat bekletildi. Süre sonunda numuneler tekrar 2500 devirde 15 dakika santrifüj edildi. Kalan sediment 0,067 $\mathrm{M}$ fosfat tamponu ( $\mathrm{pH}$ 6.8)'ndan $1 \mathrm{ml}$ ilave edilerek nötralizasyonu gerçekleştirildi.

\section{Lowenstein-Jensen (L-J) medium base}

Dehidre besiyerinden (Merck 1.05400, Germany) $37.5 \mathrm{gr}$ hassas terazide tartılarak $600 \mathrm{ml}$ distile su içinde çözündürüldü. Gliserol içerecek tüpler için hazırlanacak besiyerine $12 \mathrm{ml}$ gliserol (Merck 1.04094, Germany) ilave edildi. Besiyerine $4 \mathrm{ml}$ etil alkol içerisinde süspanse edilen $2 \mathrm{mg}$ Mycobactin J (ID.Vet, France) katılarak besiyerinin pH'sı $4.8 \pm 0.2$ olarak ayarlandı. Hazırlanan besiyerlerini içeren duran bottle şişeleri otoklavda $121^{\circ} \mathrm{C}$ 'da 15 dakika sterilize edildi ve $50{ }^{\circ} \mathrm{C}$ 'a soğutuldu. Hazırlanan yumurta (sarı ve beyaz karışık) homojenizatından gliserollü ve gliserolsüz besiyerlerine $1000 \mathrm{ml}$ ilave edildi. Ayrıca kontaminasyonları önlemek amacıyla besiyerine 100,000 U Penicillin G Potassium (Sigma P7794), 50 mg Amphotericin B (Sigma A4888) ve 50 mg Chloramphenicol (Sigma C0378) katıldı. Kültürün yapılacağı ağzı vida kapaklı steril tüplere 7'şer $\mathrm{ml}$ olacak şekilde besiyeri taksim edildi. Tüpler yatık olarak pasteur fırınında $85{ }^{\circ} \mathrm{C}$ 'da 45 dakika tutularak koagülasyona tabi tutuldu. Aynı işlem 24 saat sonra bir kez daha tekrarlandı (6).

\section{Watson-Reid agar}

Merkal ve Curran (17)'ın, bildirdiği yönteme göre hazırlandı. Bu amaçla karışım $1000 \mathrm{ml}$ distile su içinde çözündürüldü. Besiyerine $4 \mathrm{ml}$ etil alkol içerisinde süspanse edilen $2 \mathrm{mg}$ Mycobactin J (ID.Vet, France) katılarak besiyerinin pH'sı $5.5 \pm 0.2$ 'e ayarlandı. Hazırlanan besiyerini içeren duran bottle şişesi otoklavda $121{ }^{\circ} \mathrm{C}$ 'da 15 dakika sterilize edildi ve $50{ }^{\circ} \mathrm{C}$ ye soğutuldu. Kültürün yapılacağı ağzı vida kapaklı steril tüplere 7'şer ml olacak şekilde besiyeri taksim edildi. Besiyerleri gliserol ve gliserolsüz olarak işaretlendikten sonra kullanılıncaya kadar buzdolabında $4^{\circ} \mathrm{C}$ 'da saklandı.

\section{Dubos broth base}

Dehidre besiyerinden (Himedia M067, India) $1.3 \mathrm{~g}$ hassas terazide tartılarak $180 \mathrm{ml}$ distile su içinde çözündürüldü. Gliserol içerecek tüpler için hazırlanacak besiyerine $10 \mathrm{ml}$ gliserol (Merck 1.04094, Germany) ilave edildi. Besiyerine $4 \mathrm{ml}$ etil alkol içerisinde süspanse edilen $2 \mathrm{mg}$ Mycobactin J (ID.Vet, France) katılarak besiyerinin pH'sı $6.6 \pm 0.2$ 'ye ayarlandı. Hazırlanan besiyerlerini içeren duran bottle şişeleri otoklavda $121{ }^{\circ} \mathrm{C}$ 'da 15 dakika sterilize edildi ve 50 ${ }^{\circ} C^{\prime}$ ye soğutuldu. Ayrıca kontaminasyonları önlemek amaciyla besiyerine $100.000 \mathrm{U}$ Penicillin G Potassium (Sigma P7794), 50 mg Amphotericin B (Sigma A4888) ve $50 \mathrm{mg}$ Chloramphenicol (Sigma C0378) taksim edildi. Aseptik olarak hazırlanan sığır serum albumin V (Fluka 05488, UK)'den duran bottle şişelerine $20 \mathrm{ml}$ ilave edildi. Kültürün yapılacağı ağzı vida kapaklı steril tüplere 10'ar ml olacak şekilde besiyeri taksim edildi. Besiyerleri gliserol ve gliserolsüz olarak işaretlendikten sonra kullanılıncaya kadar buzdolabında $4{ }^{\circ} \mathrm{C}$ 'da saklandı (6).

\section{Mikroskopik muayene}

Hem süt numunelerinden direkt hazırlanan preparatların hem de kültürlerden izole edilen kolonilerin boyanması amacıyla Ziehl Neelsen Boyama Seti (GBL 5017) kullanıldı. Boyama prosedürü üretici firmanın bildirdiği yönteme göre yapıldı. Boyaması yapılan preparatlar mikroskopta immersiyon objektifi (100x) ile incelendi.

\section{Katı besiyeri kültür yöntemi}

Dekontaminasyon işlemi uygulanan süt örneklerinden bir öze dolusu ekim materyali alınarak gliserinli ve gliserinsiz hazırlanan Lowenstein-Jensen (L-J) Medium Base (Merck, 1.05400, Germany) besiyeri ile aynı şekilde gliserinli ve gliserinsiz hazırlanan Watson-Reid agara ekimleri yapıldı. Kültürler aerobik koşullarda $37^{\circ} \mathrm{C}$ 'de inkubasyona bırakılarak 2-8 hafta üreme yönünden incelendi (6). Besiyerlerinin kontrolü amacıyla Etlik Veteriner Kontrol Merkez Araştırma Enstitüsü Tüberküloz Paratüberküloz Ruam Teşhis Laboratuvarı'ndan temin edilen pozitif suş kullanıldı.

\section{Sıvı besiyeri kültür yöntemi}

Katı besi yerlerindeki izolatlar identifikasyon amacıyla sıvı besiyerine pasajlandı. Kültürden bir öze yardımıyla alınan şüpheli suşlar gliserinli ve gliserinsiz hazırlanan Dubos Broth Base (Himedia, M067, India)'e ekimleri yapıldı. Kültürler \%5-10 $\mathrm{CO}_{2}$ içeren ortamlarda $37^{\circ} \mathrm{C}$ 'de inkubasyona bırakılarak 2-6 hafta süresince üreme yönünden takip edildi (6). Aynı şekilde sıvı besiyerlerinin kontrolü amacıyla pozitif 
kontrol suşun da Sıvı besiyerine ekimleri gerçekleştirildi.

\section{Identifikasyon testleri}

Elde edilen izolatların identifikasyonu amacıyla katalaz, niasin, nitrat, redüksyon, pirazinamidaz ve üreaz testleri yapıldı (6).

\section{Enzyme-Linked ImmunoSorbent Assay (ELISA)}

Süt numunelerinin plazmasında mevcut antikorların tespiti amaciyla Mycobacterium paratuberculosis

\section{Mikroskobik muayene sonuçları}

Örneklerin direkt mikroskobik muayenesi sonucu 1 (\%0.5) preparatta asido-rezistans bakteriler görüldü.

\section{İzolasyon analiz sonuçları}

Kültür yöntemleri sonucu $1(\% 0.5)$ numunenin gliserinli L-J Medium'unda 6. haftada sarımsı renkte yaygın koloniler tespit edilirken aynı süt numunesinin gliserinli Watson-Reid agarında da 7 . haftada beya-

Tablo 1. Araştırma materyalinin toplandığı bölgeler ve M. paratuberculosis izolasyon oranı

\begin{tabular}{ccc}
\hline Alındığı İlçeler & Numune Sayısı & Pozitif Numune Sayısı ( \% ) \\
\hline Kocasinan & 20 & 0 \\
Melikgazi & 20 & $1(0.5)$ \\
Talas & 20 & 0 \\
Akkışla & 15 & 0 \\
Sarız & 15 & 0 \\
İncesu & 15 & 0 \\
Yahyalı & 15 & 0 \\
Pınarbaşı & 15 & 0 \\
Hacılar & 20 & 0 \\
Felahiye & 10 & 0 \\
Develi & 15 & 0 \\
Özvatan & 20 & $\mathbf{1 ( 0 . 5 )}$ \\
Toplam & $\mathbf{2 0 0}$ & 0 \\
\hline
\end{tabular}

antikor test kiti (ID Screen® Paratuberculosis Indirtect, IDVet, France)'nden kullanıldı. Testin yapılışı kiti üreten firmanın bildirdiği prosedüre göre gerçekleştirildi. Sonuçların değerlendirilmesinde KCjunior $^{\mathrm{TM}}$ software (BioTek ${ }^{\circledR}$ Instruments, Inc., United States) programı kullanıldı.

\section{Bulgular}

\section{Analiz örneklerinin alındığı yerler ve izole edilen suş sayıları}

Sokak sütlerinin mikroskobik muayene, kültür ve ELISA'dan oluşan konvansiyonel yöntemler ile incelenmeleri sonucunda, 11 ilçeden toplanan sütler MAP yönünden negatif bulundu. Sadece bir ilçeden alınan 1 (\% 0.5) sokak sütünde her üç yöntemden de pozitif sonuç elde edildi. Süt örneklerinin toplandığı yerler, numune sayıları ve izolasyonun yapıldığı ilçe Tablo 1 'de gösterildi. zımsı renkte koloniler görüldü. Bu numuneye ait gliserinsiz heriki besiyerinde ise üreme görülmedi.

\section{Identifikasyon test sonuçları}

Gliserinli L-J besiyeri ve Watson-Reid agardan izole edilen $1(\% 0.5)$ izolatın fenotipik özelliklerinin ortaya konulması amacıyla direkt mikroskopi, katalaz, niasin, nitrat, pirazinamidaz ve üreaz testlerine ait sonuçlar Tablo 2'de gösterildi.

\section{Enzyme-Linked ImmunoSorbent Assay (ELISA) sonuçları}

Serolojik incelemeler ile 1 (\% 0.5) örnek pozitif olarak bulunurken 199 (\% 99.5)'u negatif olarak tespit edildi.

\section{Tartışma ve Sonuç}

Endemik hastalıklar, hayvancılık sektöründe üretimin her aşamasında büyük kayıplara yol açmakta ve kaynak israfı oluşturmaktadır. Paratüberkülozis (Johne's disease) ruminantlarda başlıca bağırsaklarda kronik

Tablo 2. Izole edilen suşun fenotipik özelliklerin saptanmasında kullanılan testler ve sonuçları

\begin{tabular}{lccc}
\hline Testler & L-J Medium (Gliserinli) & Watson-Reid Agar (Gliserinli) \\
\hline Mikroskopi & + & + \\
Katalaz & + & + \\
Niasin & - & - \\
Nitrat & - & - \\
Pirazinamidaz & - & - \\
Üreaz & - & - \\
\hline
\end{tabular}


dejeneratif granulomatöz enteritis ile karakterize infeksiyonlar meydana getirmektedir. Bunun dişında MAP'in klinik mastitis riskini artırdığı da düşünülmektedir. Bu durum süt üretimini etkilediği için doğrudan ekonomik kayıplara neden olmakta ve başta hayvansal ürünlerin tüketimine bağlı olarak insan sağlığını da tehdit etmektedir. İnfeksiyöz etkenin morfolojik yapısına bağlı olarak bölgesel epidemilerin yaygınlık gösterdiği ve birçok işletmenin infeksiyondan etkilendiği bildirilmektedir (21).

Ülkemizde infeksiyonun varlığının ortaya konulmasında çalışmaların seroprevalans ağırlıklı olduğu kültürel ve moleküler çalışmaların ise sınırlı olduğu görülmektedir. Makav ve Gökçe (16), Kars yöresinde subklinik paratüberkülozun seroprevalansını $\% 3.5$ bulurken, Öztürk ve ark. (19) Burdur bölgesinde \%6.2 olarak bildirmişlerdir. Gümüşşsoy ve ark. (11) Kayseri bölgesinde \% 12.24 oranında sero pozitiflik tespit etmişlerdir. İkiz ve ark. (14) ile Özpınar ve ark. (20), Trakya bölgesinde sero pozitiflik tespit edememişlerdir. Yıldırım (30) Uşak bölgesinde \% 4 ve Çetinkaya ve ark. (4) Elazığ yöresinde \% 3.4 sero pozitiflik bildirmişlerdir. Mevcut çalışmalarda incelenen numune ve laboratuvar yöntemi farklılıklarına bağlı değişik sonuçlar alınmıştır. Özpınar ve ark. (20) infeksiyonu tespit edemezken Gümüşsoy ve ark. (11) \%12.24'lük bir oranla en yüksek seroprevalansı saptamışlardır. Genel olarak değerlendirildiğinde ülkemizde Avrupa ülkeleri ile karşılaştırıldığında paratüberkülozun seroprevalansının düşük olduğu görülmektedir. Çetinkaya ve ark. (4)'larının ülkemizde en fazla numune olarak 500 sığırda yaptığı çalışma göz önünde bulundurulduğunda seroprevalansın düşüklüğünün başlıca nedeni olarak düşünülmektedir. Trakyada infeksiyon saptanamamış olup Burdur dışında batı bölgelerinde infeksiyon ile ilgili bir bilgiye rastlanılmamıştır.

Paratüberkülozlu sürüler insan sağlığı açısından büyük risk oluşturmaktadır. Çiğ sütlerin ısıl işlem görmemesi ve bu sütlerin özellikle genç ve yaşı insanlar tarafından tüketilmesi süt ile bulaşmanın en önemli unsurudur. Paratüberküloza bağlı mastitislerin değerlendirilmesine yönelik çok az sayıda araştırma bulunmaktadır (11). Mevcut çalışmalar daha çok infeksiyonun süt verimi üzerindeki etkilerinin ortaya konulduğu çalışmalardır (13). Mycobacterium avium subsp. paratuberculosis'in süt numunelerinden ilk izolasyonu diğer patojenik mikroorganizmalara göre çok uzun zaman almaktadır. Bu süre yaklaşık 20 haftadır. MAP için kullanılan çok selektif bir besi yerinin bulunmaması ve var olan besiyerlerindeki kontaminasyon olasılıkları ilk izolasyonu güçleştirmektedir (5). Sweeney ve ark. (27), \%12 oranında subklinik infekte sığırların $50 \mathrm{ml}$ sütleri içerisinde yaklaşık 2-8 CFU miktarında etkenin bulunduğunu ve bu infeksiyöz etkenlerin süt ile çevreyi bulaştırabileceklerini ortaya koymuşlardır. Araştırıcılar laboratuvarda enfekte sütlerden etkenlerin izole edilememesinin bir sebebinin de süt içerisindeki bakteri yükü olduğunu belirtmişlerdir.
Isıl işlem görmesi sonucu sütlerden etkenlerin izolasyonu ile ilgili farklı çalışma sonuçları bulunmaktadır. Pastörizasyon işlemi uygulanan çiğ sütlerde MAP'nin canlı kaldığı tespit edilmiştir $(1,3)$.

Ayele ve ark. (2), üç işletmeden topladıkları 200 pastörize süt ile perakende satışa sunulan 244 pastörize sütü ZN boyama, kültür ve PCR ile incelemişlerdir. Araştırıcılar iki işletme tarafından pastörize edilen iki sütte kültür haricinde pozitiflik elde ederken ticari olarak pastörizasyonu yapılan perakende satışa sunulan sütlerden dördünde hem boyamada hem de PCR'da pozitiflik elde etmişlerdir. Ancak bu dört sütün sadece ikisinde kültürde pozitiflik görmüşlerdir. Pastörize edilen sütlerde de MAP'in bulunabileceğini ve böyle sütlerin insan sağlığı açısından risk oluşturabileceğini bildirmişlerdir. Araştırmamızda da ZN boyama, kültür ve serolojik yöntem kullanılarak MAP'in varlığının tespitine gidilmiştir. Ayele ve ark. (2) analize alınacak sütlerin dekontaminasyon aşaması da dahil izolasyonda hemen hemen aynı metodları kullanmışlardır. Araştırıcılar sütlerin analiz öncesi santrifüj edilerek pelet kısmının analize alındığını krema kısmının ise atılmasının bir handikap oluşturabileceğini vurgulamışlardır. Krema kısmında da bakteri bulunabileceğini göz önünde bulundurduğumuzda aynı görüşü paylaşmaktayız. Laboratuvar çalışmalarında MAP ile infekte makrofajların sütün yağ tabakasındaki yağ damlacıklarında bulundukları tespit edilmiştir (15). İnfeksiyöz etkenlerinin süt içerisinde yayılmasına yönelik açıklayıcı bilgiler şu an için yeterli değildir. Muhtelemen hematojen ve lenfatik yolla süte ulaştıkları düşünülmektedir. Birçok araştırıcı süt sığırlarının MAP ile infekte olduklarını ve etkenlerin süte bulaştıklarını göstermişlerdir $(9,10)$.

Paratüberkülozun serolojik olarak teşhisinde kan serumları üzerine yapılan çalışmaların yoğunluğu dikkat çekmektedir. Hendrick ve ark. (12), laktasyondaki 689 sığırdan kan, süt ve dışkı numunleri toplamışlar ve paratüberkülozun süt üretimi ve süt kalitesi üzerine etkilerini araştırmışlardır. Araştırıcılar dışkı örneklerine kültür, kan ve süt numunelerine serolojik analiz yapmışlardır. Yapılan ELISA testleri sonucu $130(\%$ $18,9)$ serum ve $77(\% 11.2)$ süt numunesinin pozitif olduğu bulunurken kültürleri yapılan dışkı örneklerinden $72(\%$ 10,4)'sinden etken izole edilmiştir. Kültür sonuçlarını baz alarak süt ELISA testinin sensitivite ve spesifitesini sırasıyla $\% 21.2$ ve $\% 98.6$ olarak belirlemişler ve süt ELISA testinin serum ELISA testine oranla kültür testine alternatif olabileceğini vurgulamışlardır. Ross ve ark. (24) MAP ile infekte olan ineklerin, klinik mastitise yakalanma olasılığının yüksek olduğunu ve MAP yönünden sürü bazında tüm hayvanların kontrolünün yapılmasının göz ardı edilemez faydalı etkilerinin bulunduğunu bildirmişlerdir.

Hendrick ve ark. (12), paratüberkülozun serolojik teşhisi amacıyla ELISA testini kullanmışlar ve test materyali olarak süt ve serumdan elde edilen sonuç- 
ların kıyaslamasını yapmışlardır. Araştırıcılar süt ELISA sonuçları pozitif olan hayvanların daha yüksek yüzdede dışkıları ile etkenleri dışarı çıkartıklarını ifade etmişlerdir. Süt ve serum ELISA uygulamaları sonucu testlerin sensitivite ve spesifitesini sırasıyla en az bir sığıra ait numunelerin analizi yapılmış ise \% 91.9 ve $\% 65.5$ ile $\% 88.9$ ve $\% 42.8$ en az iki sığırın numuneleri incelenmesi sonucu $\% 86.9$ ve $\% 93.4$ ile $\% 82.8$ ve \%79.5 olarak tespit etmişlerdir. Numune seçiminde sütün seruma oranla tercih edilebileceğini ve tek bir sığır yerine sürü içerisinde birden fazla hayvanın numunesinin incelenmesinin uygun olacağını bildirmişlerdir.

İnfeksiyonun doğal döngüsü ile birlikte subklinik infekte hayvanları tanımlayacak duyarlı ve spesifik bir testin bulunmaması kontrol programlarını yetersiz kılmaktadır. Hali hazırda infeksiyonun teşhisinde kullanılmakta olan testler hücresel ve humoral yanıtın ortaya konulmasına yönelik olup avantaj ve dezavantajları bulunmaktadır. Günümüzde infeksiyonun daha kısa sürede ve güvenilir bir şekilde teşhis edilmesi ve neticesinde gerekli önlemlerin alınabilmesi amacıyla şu an için bakteriyolojik, serolojik, alerjik ve moleküler testlerden yararlanılmaktadır. Şu an için tek bir test yönteminin teşhis için yeterli olmadığı mutlaka iki test uygulaması sonucunda kararın verilmesi görüşü ağır basmaktadır.

Kronik aşamada oluşan antikorların tanımlanmasında pratik olması ve kısa sürede sonuç vermeleri bakımından serolojik testlerin büyük avantajları bulunmaktadır. Ancak bu testler infeksiyonun erken aşamasında veya subklinik formda oluşabilecek antikorları sınırlı düzeyde tanımlamaktadır. Humoral immun yanıt etkenin vücuttan çıkarılmasından sonra etkisini göstermektedir. Çevresel Mycobacterium türlerine karşı ortaya çıkan kros reaksiyonlar serolojik testlerin spesifitesini azaltmaktadır.

Bu çalışmada Kayseri ilinde mahalle aralarında satışa sunulan sütlerin ELISA yöntemi ile incelenmesi sonucu 200 süt numunesinden sadece $1(\% 0.5)$ numunede pozitiflik saptanmıştır. Örnekler rastgele mahalle arasında satılan sütlerden aynı satıcıdan bir kere alınarak yapılmıştır. Süt toplayıcılar birçok aile işletmesinden topladıkları sütleri bir tankta toplamakta ve bunları mahalle aralarında satışa sunmaktadır. Satışa sunulan sütlerin hiçbiri soğuk zincirde deponlanmadığı ve gün boyunca perakende olarak satılıncaya kadar sürekli çevresel ısıya maruz kaldıkları görülmüştür.

Hendrick ve ark. (12), süt numunelerini ELISA ile incelemişler ve 77 (\%11.2) numunede pozitiflik saptamışlardır. Araştırmamızda kullanılan teşhis yöntemi ve kit araştırıclarınki ile aynı olup sadece bir süt numunesinde pozitiflik tespit edilmiştir. Bu durumun numune sayısının farklılığından ve numunelerin bireysel değil tank sütünden analiz yapılmasından kay- naklandığını düşündürmektedir. Araştırıclar numuneleri 9 sürü toplam 689 sığırdan numuneleri toplamışlar ve örneklerin paratüberküloz yönünden en az bir klinik semptom gösteren sığır sütü olmasına dikkat etmişlerdir.

Çetinkaya ve ark. (4), Elazığ merkeze ve ilçelere bağlı köylerden 78 farklı lokalizasyondan 500 adet süt numunesi toplamışlardır. Numuneleri sağlıklı görünüşe sahip 1.5-2 yaşın üstündeki ineklerden rastgele almışlardır. Araştırıcılar etkenin tanımlanması amacıyla başlıca PCR yöntemini kullanırken pozitif sonuç aldıkları süt numunelerinin kültürünü yapmışlardır. Pozitif sonuç alınan süt numunelerinin $17 \quad(\%$ $68)$ 'sinden kültürel yoklamalar sonucu etken izolasyonu yapmışlardır. Araştırıcılar yaptıkları mini anket çalışması sonucu paratüberküloz görülen 20 (\%5.5) ineğin tohumlanmasında boğa kullanıldığını, 4 (\%3.3) inekte suni tohumlama ve $1(\% 6.3)$ inekte ise hem boğa hem de suni tohumlama yapıldığını bildirmişlerdir. Ayrıca ineklerin ırk ve yaş gruplarına göre infeksiyonun görülme sıklığının değiştiğini ifade etmişlerdir. Araştırmamızda bizzat sokak sütleri satıcılardan toplandığı için süt numunelerinin alındığı sığır ve işletmeye ait bilgiler bulunmamaktadır. Çetinkaya ve ark. (4)'nın infeksiyon üzerine birçok faktörün etkili olabileceği ve bu faktörlere bağlı olarak paratüberkülozun artış gösterebileceğini bildirmişlerdir. Başlıca faktörler arasında iklim, beslenme, ırk, yaş, döllenme tipi ve barınak koşulları bulunmaktadır. Çalışmamızda elde ettiğimiz pozitiflik oranının düşüklüğünün bu faktörlerle yakından ilgili olabileceğini düşünmekteyiz.

Sonuç olarak, Kayseri bölgesinde yapılan süt sığırcılığında paratüberkülozun yüksek bir oranda olmasada bulunduğu görülmüştür. Bu çalışmada kullanılan serolojik yöntem sonucu elde edilen verilerin gold standart olan kültür yöntemi ile aynı sonuç vermesi hala ELISA'in rutin uygulamalar için duyarlı, pratik ve ucuz bir test yöntemi olduğunu göstermiştir. Teşhiste kullanılacak laboratuvar yöntemlerinin infeksiyonun seyrine göre hastalığın ortaya konulmasında önemli bir faktör olabileceği kanaatine varılmıştır.

Ülkemiz açısından değerlendirildiğinde ekonomik, politik veya işletmelerden kaynaklanan sebeplere bağlı olarak MAP'nin eradike edilememesi halinde, özellikle infeksiyonun kontrolünü sağlayacak aşı uygulamaları ile ilgili yoğun çalışmaların yapılması ve tüketime sunulan gida ürünlerinde mikrobiyal kontaminasyonu engelleyebilecek stratejilerin geliştirilmesi B planı olarak üzerinde durulması gereken önemli konulardır. Subklinikal infekte sığırların kısa sürede belirlenmesi sağlayabilecek rutin teşhis yöntemlerinin geliştirilmesi de paratüberkülozun sağlık problemi oluşturma özelliğini ortadan kaldırabilecektir. Ayrıca bu sadece ülkemizin sorunu olmak dışında dünyada ruminant yetiştiriciliği yapılan tüm ülkelerin problemi olarak düşünülmelidir. Bu bağlamda paratüberkülozun önemi vurgulayacak organizasyonlar düzenlen- 
meli ve infeksiyonun eradikasyonuna yönelik ülkeler arası işbirliği gerçekleştirilmelidir.

\section{Teşekkür}

TSY-10-1089 kodlu proje ile bu tez çalışmasının yapılmasındaki maddi katkılarından dolayı Erciyes Üniversitesi Bilimsel Araştırma Projeleri Birimi'ne ve pozitif kontrol suşun temini hususunda yardımlarını gördüğümüz Etlik Veteriner Kontrol Merkez Araştırma Enstitüsü Tüberküloz Paratüberküloz Ruam Teşhis Laboratuvarı Şefi Dr. Erhan AKÇAY'a teşekkür ederiz.

\section{Kaynaklar}

1. Anzabi Y, Hanifian S. Detection of Mycobacterium avium subspecies paratuberculosis in pasteurized milk by IS900 PCR and culture method. African J Microbiol Res 2012; 6(7): 1453-6.

2. Ayele WY, Svastova P, Roubal P, Bartos M, Pavlik I. Mycobacterium avium subspecies paratuberculosis cultured from locally and commercially pasteurized cow's milk in the Czech Republic. Appl Environ Microbiol 2005; 71(3): 1210-4.

3. Carvalho IA, Pietralonga PAG, Schwarz DGG, Faria ACS, Moreira MAS. Short communication: recovery of viable Mycobacterium avium subspecies paratuberculosis from retail pasteurized whole milk in Brazil. J Dairy Sci 2012; 95(12): 6946-8.

4. Çetinkaya $B$, Muz A, Ertaş $H B$, Güngör $H$, Sezen IY, Gülcü HB. Süt ineklerinde paratüberkülozun prevalansının polimeraz zincir reaksiyonu (PZR) ile saptanması. Tr J Vet Anim Sci 2000; 24(4): 371-9.

5. Djonne B, Pavlik I, Svastova P, Bartos M, Holstad G. IS900 restriction fragment length polymorphism (RFLP) analysis of Mycobacterium avium subsp. paratuberculosis isolates from goats and cattle in Norway. Acta Vet Scand 2005; 46(1-2): 13-8.

6. Drobniewski FA, Uttley AHC. Mycobacterial speciation. Parish T, Stoker NG eds. In: Mycobacteria Protocols. Towata: Humana Press Inc, 1998; pp. 323-47.

7. Dundee L, Grant IR, Ball HJ, Rowe MT. Comparative evaluation of four decontamination protocols for the isolation of Mycobacterium avium subsp. paratuberculosis from milk. Lett Appl Microbiol 2001; 33(3): 173-7.

8. Eda S, Elliott B, Scott MC, Waters WR, Bannantine JP, Whitlock RH, Speer CA. New method of serological testing for Mycobacterium avium subsp. paratuberculosis (Johne's Disease) by flow cytometry. Foodborne Pathog Dis 2005; 2(3):
250-62.

9. Florou M, Leontides L, Kostoulas P, Billinis C, Sofia M, Kyriazakis I, Lykotrafitis F. Isolation of Mycobacterium avium subspecies paratuberculosis from non-ruminant wildlife living in the sheds and on the pastures of Greek sheep and goats. Epidemiol Infect 2008; 136(5): 644-52.

10. Grant IR, Kirk RB, Hitchings E, Rowe MT. Comparative evaluation of the MGIT ${ }^{\mathrm{TM}}$ and BACTEC culture systems for the recovery of Mycobacterium avium subsp. paratuberculosis from milk. J Appl Microbiol 2003; 95(1): 196-201.

11. Gümüşsoy KS, İça T, Abay $S$, Aydın F, Hızlısoy $\mathrm{H}$. Serological and molecular diagnosis of paratuberculosis in dairy cattle. Turkish $\mathrm{J}$ Vet Anim Sci 2015; 39(2): 147-53.

12. Hendrick SH, Duffield TF, Kelton DF, Leslie KE, Lissemore KD, Archambault M. Evaluation of enzyme-linked immunosorbent assays performed on milk and serum samples for detection of paratuberculosis in lactating dairy cows. JAVMA 2005; 226(3): 424-8.

13. Hendrick SH, Kelton DF, Leslie KE, Lissemore KD, Archambault M, Duffield TF. Effect of paratuberculosis on culling, milk production, and milk quality in dairy herds. JAVMA 2005; 227(8): 13028.

14. Ikız S, Bagcıgıl AF, Ak S, Ozgur NY, Ilgaz A. Paratuberculosis in cattle in Turkey detected by PCR. Medycna Wet 2005; 61(8): 881-3.

15. Koenig GJ, Hoffsis GF, Shulaw WP, Bech-Nielsen S, Rings DM, St-Jean G. Isolation of Mycobacterium paratuberculosis from mononuclear cells in tissues, blood, and mammary glands of cows with advanced paratuberculosis. Am J Vet Res 1993; 54(9): 1441-5.

16. Makav V, Gökçe E. Kars yöresi sığırlarında subklinik paratüberkülozun seroprevalansı. Kafkas Unıv Vet Fak Derg 2013; 19(5): 913-6.

17. Merkal RS, Curran BJ. Growth and metabolic characteristics of Mycobacterium paratuberculosis. Appl Microbiol 1974; 28(2): 276-9.

18. Oken HA, Saleeb PG, Redfield RR, Schimpff SC. Is Mycobacterium avium paratuberculosis the trigger in the Crohn's Disease spectrum. Open Forum Infect Dis 2017; 4(3): 1-3.

19. Ozturk D, Pehlivanoglu F, Tok AA, Gunlu S, Guldali Y, Turutoglu $H$. Seroprevalence of paratuberculosis in the Burdur province (Turkey), in dairy cattle using the enzyme linked immunosorbent assay (ELISA). Israel J Vet Med 2010; 65(2): 53- 
7.

20. Özpınar H, Tekiner İH, Karaman O, Kurt Y. Türkiye Trakya bölgesindeki süt işletmelerinden toplanan fekal ve çiğ süt örneklerinde Mycobacterium avium subsp. paratuberculosis (MAP) incelemesi. Kafkas Univ Vet Fak Derg 2015; 21(2): 247-52.

21. Patel A, Shah N. Mycobacterium avium subsp paratuberculosis-incidences in milk and milk products, their isolation, enumeration, characterization, and role in human health. J Microbiol Immun Infect 2011; 44(6): 473-9.

22. Pierce ES. Could Mycobacterium avium subspecies paratuberculosis cause Crohn's disease, ulcerative colitis and colorectal cancer? Infect Agent Cancer 2018; 13(1): 1.

23. Robertson RE, Cerf O, Condron RJ, Donaghy JA, Heggume C, Jordan K. Review of the controversy over whether or not Mycobacterium avium subsp. paratuberculosis poses a food safety risk with pasteurised dairy products. Int Dairy J 2017; 73: 10-8.

24. Rossi G, Grohn YT, Schukken YH, Smith RL. The effect of Mycobacterium avium subspecies paratuberculosis infection on clinical mastitis occurrence in dairy cows. J Dairy Sci 2017; 100(9): 1-9.

25. Stabel JR, Steadham EM, Bolin CA. Heat inactivation of Mycobacterium paratuberculosis in raw milk: are current pasteurization conditions effective? Appl Environ Microbiol 1997; 63(12): 4975-7.

26. Stratmann J, Strommenger B, Stevenson K, Gerlach GF. Development of a peptide-mediated capture PCR for detection of Mycobacterium avium subsp. paratuberculosis in milk. J Clin Microbiol 2002; 40(11): 4244-50.

27. Sweeney RW, Whitlock RH, Hamir AN, Rosenberger AE, Herr SA. Isolation of Mycobacterium paratuberculosis after oral inoculation of uninfected cattle. Am J Vet Res 1992; 53(8): 1312-4.

28. Uzun M. Tüberküloz tanı yöntemleri LJ besiyeri ile antitüberküloz duyarlılık testi. 21 Yüzyılda Tüberküloz Sempozyumu. 11-12 Haziran, 286-289 2003; Samsun-Türkiye.

29. Whitlocka RH, Wellsb SJ, Sweeneya RW, Van Tiem J. ELISA and fecal culture for paratuberculosis (Johne's disease): sensitivity and specificity of each method. Vet Microbiol 2000; 77(3-4): 38798.

30. Yıldırım D, Civelek T. Prevalence of subclinical paratuberculosis in dairy cattle in Uşak region. Kafkas Unıv Vet Fak Derg 2013; 19(1): 121-6. 